\title{
ANTIOXIDANT AND ANTI-INFLAMMATORY PROPERTIES OF PTEROSPERMUM RUBIGINOSUM HEYNE EX WIGHT AND ARN AND PTEROSPERMUM RETICULATUM WIGHT AND ARN (STERCULIACEAE): AN IN VITRO COMPARATIVE STUDY
}

\author{
JENSON JACOB, SREEJITH K* \\ Department of Biotechnology and Microbiology, Kannur University, Kannur, Kerala, India. Email: sreejithkrishnan@hotmail.com \\ Received: 27 June 2018, Revised and Accepted: 25 October 2018
}

\section{ABSTRACT}

Objectives: Plants from the family Sterculiaceae are used as folk medicine for treating various diseases in India. This study aims to determine the antioxidant and anti-inflammatory properties of Pterospermum rubiginosum and Pterospermum reticulatum of the family Sterculiaceae. The barks of $P$. rubiginosum and P. reticulatum are used in traditional medicine especially in the treatment of wounds, sprains, bone fracture, etc. This study, we compare the antioxidant and anti-inflammatory potentials of the stem bark of these two plants.

Methods: The free radical scavenging assays such as 2,2-diphenyl,1-picrylhydrazyl (DPPH), 2,2'-azino-bis(3-ethylbenzothiozoline-6-sulfonic acid) (ABTS), hydroxyl radical, nitric oxide radical, phosphormolybdenum assay, and reducing power assay are used for the measurement of antioxidant potentials. The in vitro anti-inflammatory activities of the extracts are evaluated by means of lipoxygenase (LOX) and protease inhibition.

Results: Both P. rubiginosum and P. reticulatum scavenge DPPH (70.10\% and 91.02\%), ABTS (94.48 and 98.19\%), hydroxy (76.02 and 87.67\%), and nitric oxide (87.02 and 80.84\%) radicals. Phosphomolybdenum assay and reducing power assay, used for the measurement of antioxidant potentials also showed good results. Regarding the anti-inflammatory potential, the methanolic extract of the plants shows anti-protease activity (51.29 and $64.93 \%$ ) and anti-LOX activity (56\%) while P. rubiginosum does not exhibit anti-LOX activity.

Conclusion: The above results demonstrate that the plants $P$. rubiginosum and $P$. reticulatum are rich source of antioxidant and anti-inflammatory compounds and it is the first report on theantioxidant and anti-inflammatory properties of the barks of these plants.

Keywords: Antioxidants, Free radicals, Inflammation, Oxidative stress, Pterospermum reticulatum, Pterospermum rubiginosum.

(c) 2019 The Authors. Published by Innovare Academic Sciences Pvt Ltd. This is an open access article under the CC BY license (http://creativecommons. org/licenses/by/4. 0/) DOI: http://dx.doi.org/10.22159/ajpcr.2019.v12i2.28137

\section{INTRODUCTION}

The production of free radicals such as superoxide, peroxide, and nitric oxide harms macromolecules such as proteins, lipids, and nucleic acids in human cells. This will lead to diseases such as cancer, acute, and chronic inflammatory conditions such as rheumatoid arthritis, atherosclerosis, and aging [1-6]. The antioxidant enzymes and antioxidant compounds such as ascorbic acid, tocopherol, and glutathione prevent the cells from the possible harms that free radicals can cause or they act as "free radical scavengers." Inflammation is a response of body tissues to the harmful effects caused by physical injury, chemical substances, and certain microbial agents. It is initiated by the release of inflammatory mediators from injured tissues and migrating cells [7]. This problematic condition attracted the researchers to study the effect of antioxidant activity in inflammatory diseases. In spite of the discovery of several novel agents, the search for better anti-inflammatory drugs still continues due to their side effects, especially during the prolonged course. In this context, various potent drugs of plant origin are used widely in Indian traditional system of medicine.

Pterospermum rubiginosum is a tree which belongs to the family Sterculiaceae in evergreen forests of Indian states such as Assam, Karnataka, Tamil Nadu, and Kerala at an altitude of up to $1000 \mathrm{~m}$. Although the bark of P. rubiginosum has been reported to be a traditional medicine in India, the anti-inflammatory and antioxidant effect of it remains unexplored. Pterospermum reticulatum is also a medicinally important tree belonging to the same family. This tree is found in the evergreen forests of Western Ghats of India at low altitudes, and the stem bark of this plant had been used in India to treat ulcers, wounds, and inflammation. However, there are no reliable scientific reports available regarding the in vitro antioxidant and anti-inflammatory potentials of the barks of these two plants. The present work focuses on in vitro antioxidant and anti-inflammatory activity of methanolic extracts from the bark of $P$. rubiginosum and $P$. reticulatum considering the ethnomedical importance of these plants.

\section{METHODS}

Collection, authentication, and extraction of bark materials The bark of $P$. rubiginosum and $P$. reticulatum was collected from Swaminathan Research Foundation and Tropical Botanical Garden Research Institute, Kerala, India. The bark material was identified and authenticated from the Department of Botany, Government Brennen College, Thalassery, under Kannur University. The specimen was preserved in the College Herbarium (Voucher.No.16315 and 16314). The barks of the $P$. rubiginosum and $P$. reticulatum (30 g each) were dried in the shade and then powdered using a mechanical grinder. The powdered bark materials were subjected to methanol $(300 \mathrm{ml})$ extraction using Soxhlet apparatus. The solvent was completely removed using rotor evaporator and the extract (5.1 g and $3.9 \mathrm{~g}$ ); thus, obtained was stored for further use.

\section{EVALUATION OF IN VITRO ANTIOXIDANT ACTIVITIES}

The antioxidant activity of the methanolic extracts from the bark of $P$. rubiginosum and $P$. reticulatum was evaluated and measured by the following methods such as 2, 2-diphenyl, 1-picrylhydrazyl (DPPH) assay [8], 2,2-azino-bis(3-ethylbenzothiozoline-6-sulfonic acid) (ABTS) assay [9], nitric oxide radical scavenging assay [10], and hydroxyl radical scavenging assay [11]. The $\mathrm{IC}_{50}$ of the bark extracts were calculated. Phosphomolybdenum assay [12] and reducing power assay [13] were also determined. The assays were done at a concentration ranging from $200 \mu \mathrm{g} / \mathrm{ml}$ to1000 $\mu \mathrm{g} / \mathrm{ml}$ for both the sample. 
Evaluation of anti-inflammatory activities

\section{Antiprotease activity}

The enzymatic assay for trypsin inhibition was carried out using the spectrophotometric assay by Sigma-Aldrich with certain modifications. In the experiment, $200 \mu \mathrm{l}$ of trypsin is added with $200 \mu \mathrm{l}$ of the sample solution and incubated for $10 \mathrm{~min}$. The reaction is then initiated by the addition of $3 \mathrm{ml}$ of substrate N-benzoyl-L- arginine ethyl ester and the absorbance is measured at $253 \mathrm{~nm}$ for $10 \mathrm{~min}$ using ultraviolet (UV) visible spectrophotometer. Phenyl methyl sulfonyl fluoride (PMSF), a known trypsin inhibitor is used as positive control. The inhibition of trypsin is calculated by following the equation:

$$
\text { Inhibition }(\%)=(1-\mathrm{B} / \mathrm{A}) \times 100
$$

Where A is the change in absorbance without test sample and B is the change in absorbance with the test solution.

\section{In vitro lipoxygenase (LOX) inhibition assay}

The inhibition of LOX is determined by spectrophotometric assay using Soybean LOX-13. The substrate linoleic acid is used for the experiment. The conversion of linoleic acid to 13-hydroperoxy linoleic acid is followed spectrophotometrically by the appearance of a conjugated diene at $234 \mathrm{~nm}$ on a UV/visible spectrophotometer with some modifications, and the reaction rate is determined [14]. The mixture which contains $50 \mu \mathrm{l}$ of LOX enzyme added with $50 \mu$ of test solution of suitable concentration and is incubated for $1 \mathrm{~min}$. Different volumes of the buffer are added to this mixture, and the reaction is initiated by adding $360 \mu \mathrm{l}$ substrate and recorded at $234 \mathrm{~nm}$ for $5 \mathrm{~min}$ using UV-visible spectrophotometer. Vanillin, a known inhibitor of LOX, is used as a standard.

The inhibition of LOX, calculated by following the equation:

$$
\text { Inhibition }(\%)=(1-\mathrm{B} / \mathrm{A}) \times 100
$$

Where A is the change in absorbance without test sample and B is the change in absorbance with the test solution.

\section{RESULTS AND DISCUSSION}

This study puts forward the use of natural antioxidants in the treatment of diseases caused by oxidative stress and inflammatory conditions. Plants are the important source of natural antioxidants. The usefulness of natural antioxidants in preventing the harmful consequences of oxidative stress and inflammatory conditions has created an increasing interest in the protective biochemical functions of natural antioxidants contained in medicinal plants [15]. The two medicinal plants $P$. rubiginosum and $P$. reticulatum have not been reported yet for their activity against oxidative stress and inflammation. The methanolic extract yield of $P$. rubiginosum and $P$. reticulatum taken for the analysis is $17 \%$ and $13 \%$, respectively.

\section{In vitro free radical scavenging effect of the extract \\ DPPH method}

The percentage of scavenging was $7.71 \pm 0.73$ at a minimum concentration of $200 \mu \mathrm{g} / \mathrm{ml}$ and $70.10 \pm 1.82$ at a maximum concentration of $1000 \mu \mathrm{g} / \mathrm{ml}$ for $P$. rubiginosum. The percentage of scavenging activity of $P$. reticulatum showed inhibition of $50 \pm 0.19$ at an initial concentration of $200 \mu \mathrm{g} / \mathrm{ml}$ and $91 \%$ at a concentration of $1000 \mu \mathrm{g} / \mathrm{ml}$ (Fig. 1). Although both the plants exhibited a significant radical scavenging effect on the DPPH radicals, the effect was higher for $P$. reticulatum when compared to P. rubiginosum. The $\mathrm{IC}_{50}$ of $P$. rubiginosum was found to be $0.714 \mathrm{mg} / \mathrm{ml}$ where as the $P$. reticulatum shows an $\mathrm{IC}_{50}$ of $0.15 \mathrm{mg} / \mathrm{ml}$. Similarly, some Algerian medicinal plants such as Olea europaea and Ziziphus lotus scavenge DPPH radicals with increased concentrations [16].

\section{ABTS radical scavenging assay method}

The percentage of scavenging in P. rubiginosum ranged from $54.66 \pm 1.54$ with a minimum concentration range of $200 \mu \mathrm{g} / \mathrm{ml}$ and $94.48 \pm 0.83$ at a maximum concentration of $1000 \mu \mathrm{g} / \mathrm{ml}$. P. reticulatum showed inhibition of $98 \%$ at a high concentration of $1000 \mu \mathrm{g} / \mathrm{ml}$ (Fig. 2). It proves that the plant extract is useful for treating free radical-related inflammatory disorders. The $\mathrm{IC}_{50}$ of $P$. rubiginosum was found to be $0.182 \mathrm{mg} / \mathrm{ml}$ whereas the P. reticulatum showed an IC ${ }_{50}$ of $0.166 \mathrm{mg} \mathrm{ml}$. Similarly, the plant Pedilanthus tithymaloides under Euphorbiaceae shows high inhibition of $98.56 \%$ on stable ABTS radicals [17].

\section{Hydroxyl radical scavenging assay method}

The methanolic extract of $P$. rubiginosum extract showed better scavenging activity for hydroxyl free radicals, and the percentage of scavenging ranges from $21.31 \pm 1.55$ for a minimum concentration of $200 \mu \mathrm{g} / \mathrm{ml}$ to $76.02 \pm 1.87$ at a maximum concentration range of $1000 \mu \mathrm{g} / \mathrm{ml}$. In the case of $P$. reticulatum, the inhibition was found to be $87 \%$ for methanol extract of the bark at a high concentration of $1000 \mu \mathrm{g} / \mathrm{ml}$ (Fig. 3). The $\mathrm{IC}_{50}$ of $P$. rubiginosum was found to be 0.648 $\mathrm{mg} / \mathrm{ml}$ whereas the P. reticulatum showed an $\mathrm{IC}_{50}$ of $0.512 \mathrm{mg} / \mathrm{ml}$.

\section{Nitric oxide scavenging assay method}

A better scavenging activity for nitric oxide radicals was observed for P. rubiginosum at a range from $51.31 \pm 0.55$ at a minimum concentration of $200 \mu \mathrm{g} / \mathrm{ml}$ to $87.02 \pm 2.59$ at a maximum concentration of $1000 \mu \mathrm{g} / \mathrm{ml}$. P. reticulatum showed $81 \%$ activity at a high concentration of $1000 \mu \mathrm{g} / \mathrm{ml}$ (Fig. 4). Nitric oxide is involved in oxidative stress and various inflammatory processes, and it acts as a potent inhibitor for several processes such as relaxation of smooth muscles, neuronal signaling, and aggregation of blood platelets [18]. Better nitric oxide scavenging activity shown by both $P$. rubiginosum and $P$. reticulatum is a good indication of its usefulness in the treatment of inflammation. The $\mathrm{IC}_{50}$ of $P$. rubiginosum was found to be $0.195 \mathrm{mg} / \mathrm{ml}$ whereas the $P$. reticulatum showed an $\mathrm{IC}_{50}$ of $0.2 \mathrm{mg} / \mathrm{ml}$.

\section{In vitro antioxidant activity of the extract}

Ferric reducing power assay

About $50 \mu \mathrm{g} / \mathrm{ml}$ equivalents of standard ascorbic acid were found to be equivalent to $200 \mu \mathrm{g} / \mathrm{ml}$ of the methanolic extract of $P$. rubiginosum, and

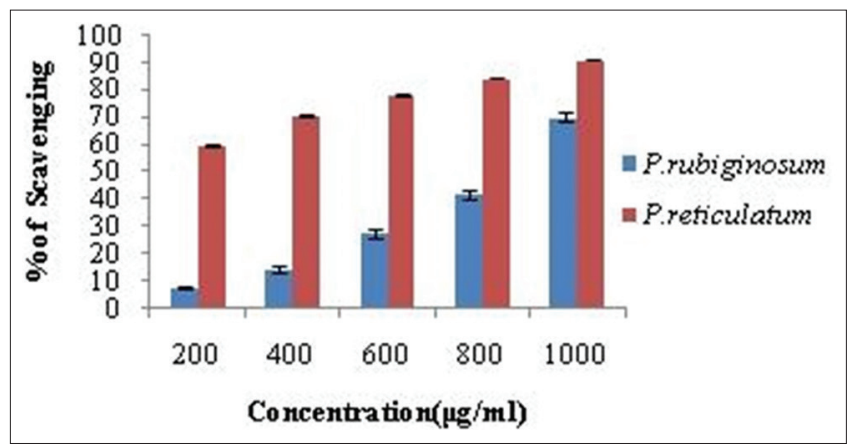

Fig. 1: Percentage scavenging (mean \pm standard deviation) by 2,2diphenyl,1-picrylhydrazyl assay

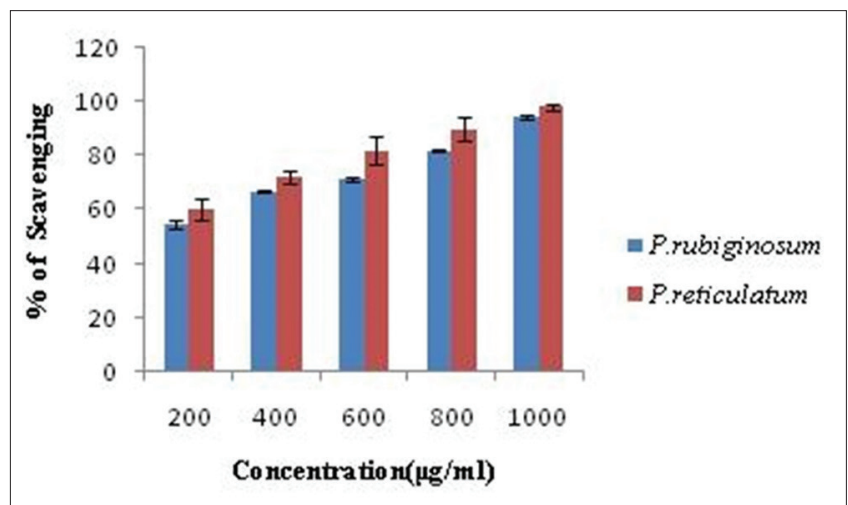

Fig. 2: Percentage scavenging (mean \pm standard deviation) by 2,2'azino-bis(3-ethylbenzothiozoline-6-sulfonic acid) assay 
$200 \mu \mathrm{g} / \mathrm{ml}$ of methanolic bark extract of $P$. reticulatum was found to be equivalent to $77 \mu \mathrm{g} / \mathrm{ml}$ of ascorbic acid (Fig. 5). As the optical density of these bark extracts is very high, its reductive ability increases. These plant extracts have natural antioxidants to donate electrons and to reduce Fe+3$\mathrm{Fe}+2$ ions. Hence, both the plants have better reducing power activity.

\section{Phosphomolybdenum assay}

Phosphomolybdenum assay was used for screening antioxidant activity of plant extracts. Here, $200 \mu \mathrm{g} / \mathrm{ml}$ of the P. rubiginosum was found to be equivalent to $128 \mu \mathrm{g} / \mathrm{ml}$ of standard ascorbic acid. However, in P. reticulatum $200 \mu \mathrm{g} / \mathrm{ml}$ of bark methanol extract was found to be equivalent to $100 \mu \mathrm{g} / \mathrm{ml}$ of ascorbic acid (Fig. 6). Increase in optical density indicates a higher antioxidant activity of the plant. The methanolic extracts of both the plants reduced Mo (VI) to Mo (V) in the presence of natural antioxidants, which are found in these medicinal

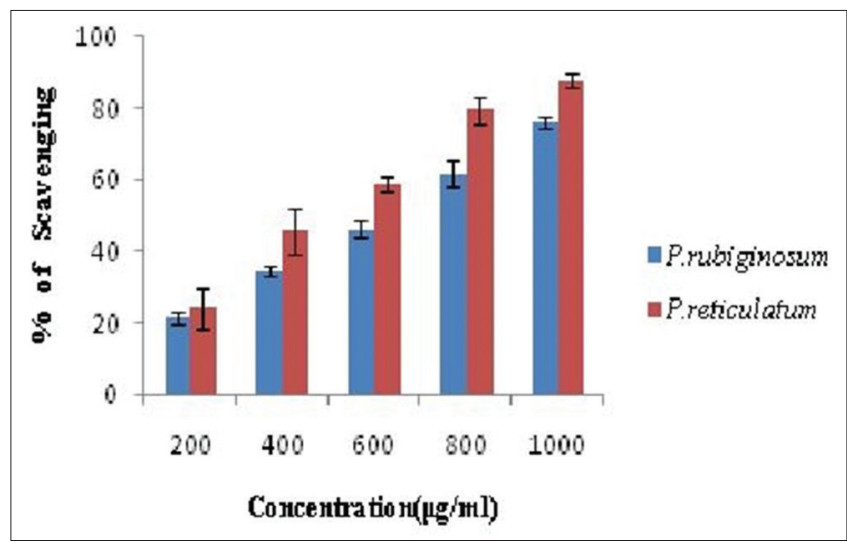

Fig. 3: Percentage scavenging (mean \pm standard deviation) by hydroxy radical scavenging assay

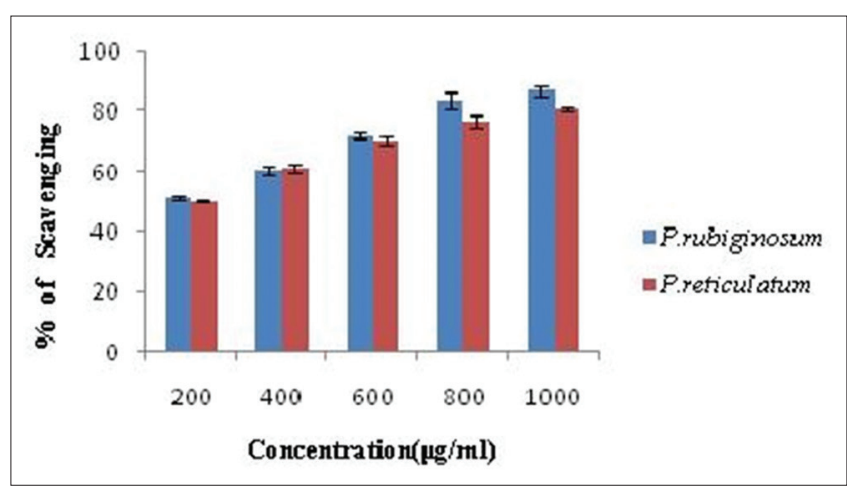

Fig. 4: Percentage scavenging (mean \pm standard deviation) by nitric oxide scavenging assay

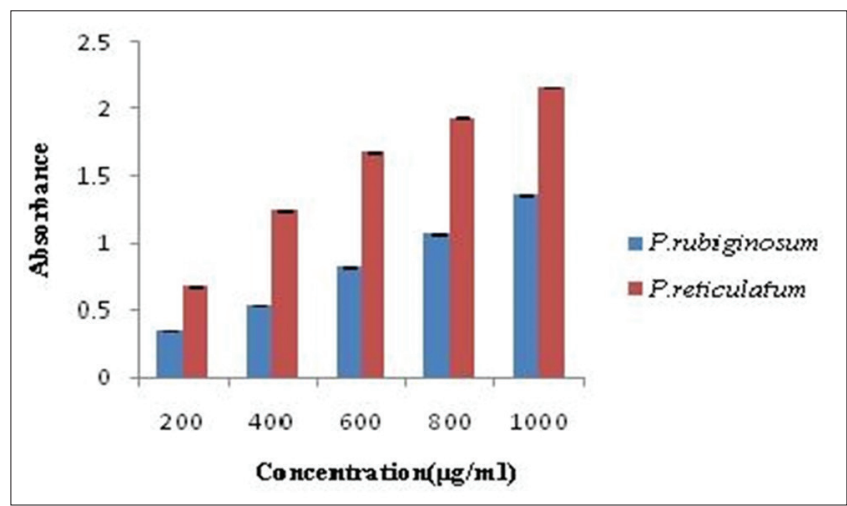

Fig. 5: Antioxidant activity by ferric reducing power assay plants. Thus, the activity increases with increase in the concentration of $P$. rubiginosum and $P$. reticulatum

\section{In vitro anti-inflammatory assays}

Antiprotease activity

$P$. rubiginosum and $P$. reticulatum exhibited significant antiprotease activity at different concentrations. P. rubiginosum showed an inhibition of $51.29 \%$ at $500 \mu \mathrm{g} / \mathrm{ml}$ and $P$. reticulatum showed an inhibition of $64.93 \%$ at $500 \mu \mathrm{g} / \mathrm{ml}$ whereas PMSF, a standard protease inhibitor showed $55.19 \%$ of inhibition at $100 \mu \mathrm{g} / \mathrm{ml}$ (Fig. 7). Neutrophils contain proteases localized in lysosomes, and these proteases are involved in the development of tissue damage during chronic inflammatory conditions [19]. In this study, P. rubiginosum and P. reticulatum proved to be having efficient antiprotease activity, which may help in overcoming inflammatory conditions.

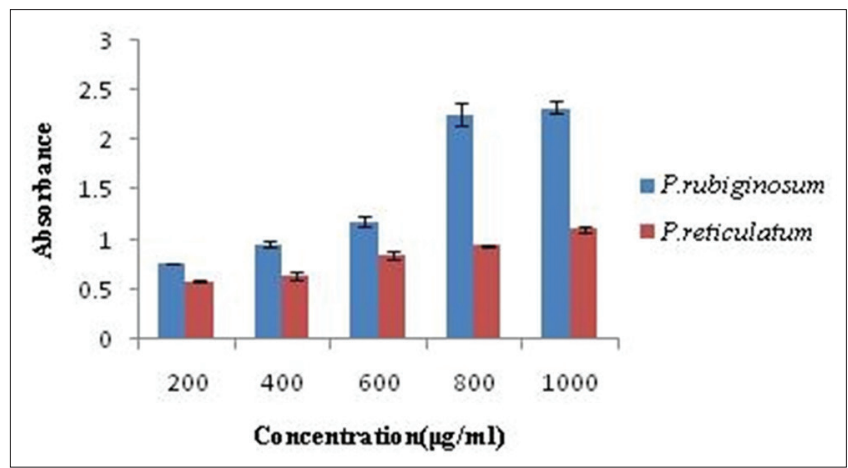

Fig. 6: Antioxidant activity by phosphomolybdenum assay

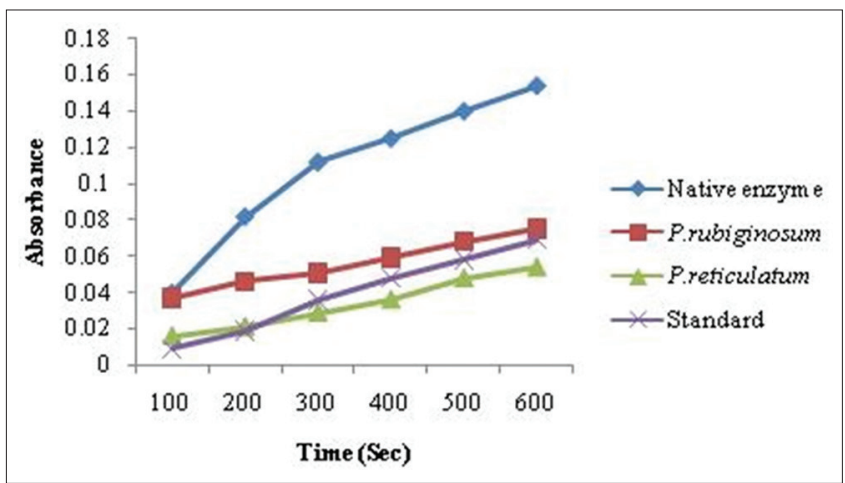

Fig. 7: Antiprotease activity of Pterospermum rubiginosum and Pterospermum reticulatum

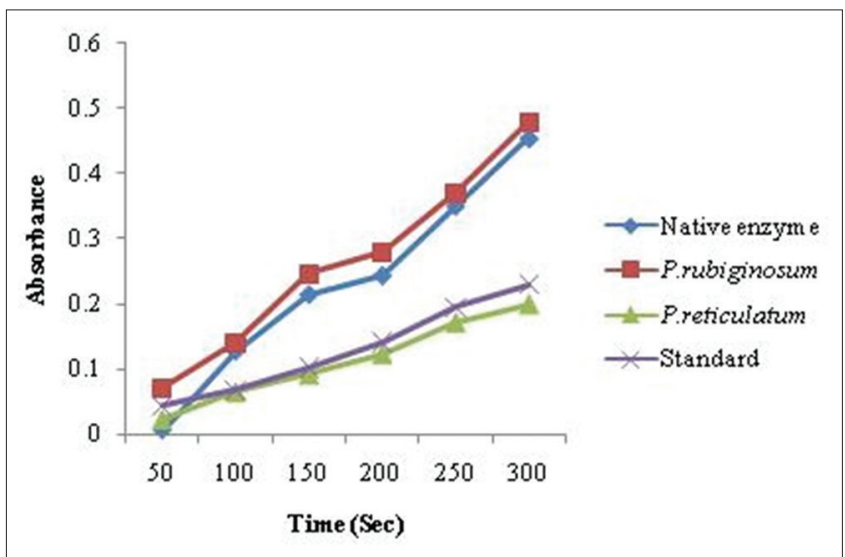

Fig. 8: Antilipoxygenase activity of Pterospermum rubiginosum and Pterospermum reticulatum 


\section{In vitro LOX inhibition assay}

Soybean 13-LOX was used for this study as it is found to be one of the most stable enzymes among LOXs. The methanolic bark extract of $P$. reticulatum showed $56 \%$ inhibition whereas $P$. rubiginosum showed no inhibition at a concentration of $500 \mu \mathrm{g} / \mathrm{ml}$. The standard inhibitor vanillin shows inhibition of $49.33 \%$ at a concentration of $100 \mu \mathrm{g} / \mathrm{ml}$ (Fig. 8). In our findings, P. reticulatum acted as an inhibitor for LOX, which plays a key role in the prostaglandin biosynthesis, where the prostaglandins are the mediators of inflammation. Therefore, this activity can be made useful against various inflammatory disorders in the human system.

\section{CONCLUSION}

This study shows that the plants $P$. rubiginosum and $P$. reticulatum are rich sources of antioxidants and anti-inflammatory compounds. It is the first report in which the antioxidant and anti-inflammatory properties of these plants have been investigated. These findings now need to be validated with animal models for better management of human diseases resulting from oxidative stress and inflammation. The efforts for purification and identification of the active compounds from both the plants are still in progress.

\section{ACKNOWLEDGMENT}

The authors are thankful to Inter University Centre for Biosciences (IUCB), Kannur University, for providing the facilities for this work.

\section{AUTHORS' CONTRIBUTION}

Jenson Jacob collected the data, conducted the experiment, and prepared the article. Dr. K. Sreejith, Professor, supervised the experiments and reviewed the article.

\section{CONFLICTS OF INTEREST}

Authors declare that they have no conflicts of interest.

\section{REFERENCES}

1. Halliwell B. Oxygen radicals and metal ions: Potential anti-oxidant intervention strategies. Ann Intern Med 1987;107:526-45.

2. Halliwell B, Gutteridge JM. Free Radicals in Biology and Medicine. New York: Oxford University Press; 1999.

3. Mahajan A, Tandon VR. Antioxidants and rheumatoid arthritis. J Indian Rheumatol Assoc 2004;12:139-42.
4. Middleton E Jr., Kandaswami C, Theoharides TC. The effects of plant flavonoids on mammalian cells: Implications for inflammation, heart disease, and cancer. Pharmacol Rev 2000;52:673-751.

5. Winrow VR, Winyard PG, Morris CJ, Blake DR. Free radicals in inflammation: Second messengers and mediators of tissue destruction. Br Med Bull 1993;49:506-22.

6. Lee J, Koo N, Min DB. Reactive oxygen species, aging and antioxidative nutraceuticals. Compr Rev Food Sci Food Saf 2004;3:21-3.

7. Bhitre MJ, Fulmali S, Kataria M, Anwikar S, Kadri H. Antiinflammatory activity of the fruits of Piper longum Linn. Asian J Chem 2008;20:4357-60.

8. Brand-Williams W, Duvalier ME, Berset C. Use of a free radical method to evaluate antioxidant activity. Food Sci Technol 1995;28:25-30.

9. Thaipong K, Boonprakob U, Crosby K. Comparison of ABTS, DPPH, FRAP, and ORAC assays for estimating antioxidant activity from guava fruit extracts. J Food Compost Anal 2006;19:669-75.

10. Ilavarasan R, Mallika M, Venkataraman S. Anti-inflammatory and antioxidant activities of Cassia fistula Linn bark extract. Afr J Trad 2005;2:70-85.

11. Sudha M, Priya S, Shree RI, Vadivukkarasi S. In vitro free radical scavenging activity of raw pepino fruit (Solanum muricatum Aiton). Int J Curr Pharm 2011;3:98-110.

12. Prieto P, Pineda M, Aguilar M. Spectrophotometric quantitation of antioxidant capacity through the formation of a phosphomolybdenum complex: Specific application to the determination of Vitamin E. Anal Biochem 1999;269:337-41

13. Oyaizu M. Studies on products of browning reaction: Antioxidative activity of product of browning reaction prepared from glucosamine. Jap J Nutr Diet 1986;44:307-15.

14. Anthon GE, Barret DM. Colorimetric method for the determination for the determination of lipoxygenase activity. J Agric Food Chem 2001;49:32-7

15. Noida Y, Anzai-Kmori A, Kohono M, Shimnei M, Packer L. Hydroxyl and superoxide anion radical scavenging activities of natural source antioxidants using the computerized JES-FR30 ESR spectrometer system. Biochem Mol Biol Int 1997;42:35-44.

16. Saiah H, Allem R, El Kebir ZF. Antioxidant and antibacterial activities of six Algerian medicinal plants. Int J Pharm Pharm Sci 2015;8:367-74.

17. Prakashi NK, Kumar MR, Sripriya N, Lekshmi RP, Deepa S, Bhuvaneswari S. Antioxidant, free radical scavenging activity and GC-MS studies on Pedilanthus tithymaloides (L.). Int J Pharm Pharm Sci 2014;6:284-7.

18. Karuppagounder SS, Madathil SK, Pandey M, Haobam R, Rajamma U, Mohanakumar KP. Quercetin up-regulates mitochondrial complex-I activity to protect against programmed cell death in rotenone model of Parkinson's disease in rats. Neuroscience 2013;16:136-48

19. Das SN, Chatterjee S. Long term toxicity study of ART-400. Indian Indg Med 1995;16:117-23. 